\title{
Income Tax Reform in Canada: The Report of the Royal Commission on Taxation
}

\author{
Boris I. Bittker
}

The 1966 Report of the Royal Commission on Taxation, ${ }^{1}$ established with a sweeping mandate to examine the federal tax laws of Canada and to make recommendations for their improvement, has few peers among modern proposals for income tax reform. Its only rivals in this country are the two collections of tax reform proposals assembled in 1955 and 1959 by the Joint Economic Committee and the House Ways and Means Committee, which could range more speculatively over the tax landscape because they consisted of separate papers submitted by a medley of experts, but which for the same reason lacked the cohesiveness that marks the Canadian Commission's program. The 1953-1955 reports of the British Royal Commission on the Taxation of Profits and Income are of comparable interest and quality, but they lack the boldness of the Canadian report, and at points require such a familiarity with the details of the United Kingdom's existing income tax law as to discourage the outsider. The only other comparable projects with which I am familiar are the 1949 recommendations of the Shoup Mission for the reform of the Japanese tax system and Nicholas Kaldor's 1954 prescription for India; neither has received the attention it deserves, the former having been discounted because of its military sponsorship and the latter because of an assumption that a plan devised for India would inevitably be destined for exhibition rather than use and hence would not have to be anchored in reality. The talent contributing to the American Law Institute's Federal Income Tax Project of the early 1950 's could have produced a landmark of analysis and innovation, but its objective was "an improvement of the technical provisions of the present income tax statute" and it was faithful to this limited commitment. ${ }^{2}$

Boris I. Bittker is Southmayd Professor of Law, Yale University.

1 Report of the Royal Commission on Taxation (Ottawa, 1966) [hereinafter cited as REPORT]. The Report consists of six volumes, plus a consolidated index, and the Commission also published a large number of supporting staff studies, including a 389-page volume of computer programs and data used in predicting the quantitative impact of its recommendations.

2 In the order cited, these reports are: JOINT CoMmITteE on THE ECoNomic REPORT, 
There can be no doubt that the "Carter Report," to give it the name of the Canadian Commission's distinguished chairman, Kenneth LeM. Carter, belongs in this select company. Quite aside from the merits of its conclusions, some of which I shall discuss in this review, the Report is marked by lucidity of analysis, candor in exposing its presuppositions, fairness in the presentation of alternatives, and modesty in disclaiming infallibility. It is, in short, not a White Paper desigued to prop up a debatable fait accompli, but a work of scholarship, culminating in recommendations for action, that frankly acknowledges when it moves beyond the boundaries of objectivity and expertise, rather than seeking to blur or shift these limits. Whether its recommendations survive the legislative vagaries of Canadian politics or not, for the foreseeable future the Report will be a starting point for any responsible program of income tax reform in an industrialized country, as well as a prod to the reexamination of many issues, theoretical and practical, in the taxation of income. It has already evoked the attention of many commentators who, whatever their separate orientations and reservations, have paid tribute to the Report's importance. ${ }^{3}$

From a wide range of possibilities, I have selected for review here the rationale underlying the Commission's income tax rate structure, definition of the taxpayer unit, and treatment of business entities and other financial intermediaries. Lest the criticisms which I offer be thought inconsistent with my introductory encomium, the reader should not lose sight of the obvious fact that disagreement is usually more congenial to the scholar than consensus.

\section{Discrettonary Economic PoWer}

Although the Commission's advocacy of a comprehensive income tax base has attracted special attention, its ultimate judgment that taxes should be allocated in proportion to the "discretionary economic power" of taxpaying units is of at least equal importance, and of greater

Federal TAX Policy for Economic Growth and Stability, 84th Cong., 2nd Sess. (1956); House Commrttee on Ways and Means, TAX Revision Compendium (3 vols., 1959); REport of THE ROyal Commission on the TAXation of Profits and Income (1953, Cind. 8761, and 1955, Cmd. 9474); Report on Japanese TaXation submitted to the Supreme COMMANDER FOR THE AIIIED Powers (4 vols., 1949); N. KaLdOR, INDIAN TAX REPORM, Report of a Survey (New Delhi, 1954); ALI, Fed. Income Tax Stat. (2 vols, 1954).

3 See, inter alia, Canabian Tax foundation, Report of Proceedings of the Twentieth Tax Conference (Montreal, 1968); J. Pechman, Report of the Canadian Royal ComMISSION on TAXation: A Summing Up (Brookings, 1967); Brazer, Review of the Report, 15 Canadian Tax J. 273 (1967); Robertson, $A$ Perspective on the Report, I5 Canadian TAX J. 230 (1967); Smith, The Report of the Royal Commission on Taxation: A Critique, 19 TAX EXEc. 215 (1967); Comment, Income Averaging: A Canadian Suggestion, 77 YALE L.J. 1223 (1968). 
originality. ${ }^{4}$ In making "discretionary economic power" the core of its tax structure, the Commission asserts that a taxpaying unit's ability to pay is most accurately measured by the portion of its "total economic power that does not have to be exercised to maintain the members of the unit"-maintenance being not "bare, physical subsistence," but the "appropriate standard of living of the family or unattached individual relative to others."' Thus, a "comprehensive tax base" turns out to be the Commission's way of ascertaining the taxpaying unit's "total economic power," but this concept is simply a way station on the road to the Commission's real destination-" discretionary economic power."

In measuring "ability to pay" by the amount of income available for the taxpayer's "discretionary" use after providing for his "appropriate standard of living ... relative to others," the Commission diverges decisively from the contrary view that, aside from an exemption for basic subsistence and possibly for unusual medical expenses and other catastrophies, ability to pay is synonymous with the taxpayer's ability to command goods and services of all types. In traditional income tax theory, it is quite irrelevant (at levels above subsistence, and aside from relief for catastrophic losses) whether the taxpayer must use his entire income to maintain his "appropriate standard of living," or can indulge in "discretionary" expenditures. Statutory allowances taking account of the way a taxpayer chooses to spend his income are customarily criticized unless they serve an objective that cannot be effectively achieved by a non-tax route; because they are viewed as inconsistent with a proper measure of the taxpayer's ability to pay, such allowances must meet a heavy burden of proof before they are tolerated, let alone welcomed, by orthodox commentators.

By contrast, the Commission's use of "discretionary economic power" as the proper measure of ability to pay invites, indeed makes indispensable, a distinction between the income that is required to maintain the taxpayer's "appropriate standard of living," and the income that permits him to extend himself. The Commission establishes this dividing line by a set of assumptions about the relationship between total income and discretionary income, supplemented by provisions to take account of certain specific non-discretionary expenses that may vary for taxpayers within any income bracket. The assumptions are: (a) Below

4 I had completed a draft of this portion of my article before the publication of Blum, Progressive Taxation Reconsidered-North of the Border, 45 TAxEs 718 (1967), and I have not revised it to take account of his trenchant comments on the Commission's report. We have focussed on different aspects of the Commission's "discretionary income" theory, and, though our conclusions run on parallel rather than converging tracks, they can be described as not inconsistent.

53 REPORT 5. 
a specified level of income, nothing is left over for discretionary expenditures; (b) above $\$ 100,000$, all income is available for such uses; and (c) between these two limits, an increasing fraction of each increment of income can be used for discretionary expenditures. ${ }^{\circ}$ As applied by the Commission, these assumptions produce the following fractional and dollar amounts of discretionary income: ${ }^{7}$

\begin{tabular}{|c|c|c|}
\hline $\begin{array}{c}\text { Income Bracket } \\
\$\end{array}$ & $\begin{array}{c}\text { Assumed Fraction } \\
\text { of Income in the } \\
\text { Bracket Available } \\
\text { for Discretionary } \\
\text { Use }\end{array}$ & $\begin{array}{l}\text { Discretionary Income } \\
\text { Cumulative total to } \\
\text { top of bracket } \\
\$\end{array}$ \\
\hline $0-\quad 195$ & 0.0 & 0 \\
\hline 195- $\quad 390$ & 0.1 & 20 \\
\hline 390- $\quad 781$ & 0.2 & 98 \\
\hline $781-1,562$ & 0.3 & 332 \\
\hline $1,562-\quad 3,125$ & 0.4 & 958 \\
\hline $3,125-6,250$ & 0.5 & 2,520 \\
\hline $6,250-12,500$ & 0.6 & 6,270 \\
\hline $12,500-25,000$ & 0.7 & 15,020 \\
\hline $25,000-50,000$ & 0.8 & 35,020 \\
\hline $50,000-100,000$ & 0.9 & 80,020 \\
\hline $100,000-200,000$ & 1.0 & 180,020 \\
\hline
\end{tabular}

The amounts in the third column of this table would be reduced, by virtue of specific allowances in the Commission's proposals, for taxpayers who incur extraordinary medical expenses or support a close relative, as well as for working mothers with young children.

At first blush, it may be thought that there is nothing original in the Commission's selection of "discretionary income" as the proper measure of taxpaying ability, as compared with the traditional choice of aggregate income; what counts in the end is the amount of tax paid, and by manipulating the tax rate, the same tax can be imposed on any taxpayer whether we look to his aggregate income or only to his discretionary income. Thus, for the table above, a rate schedule could be devised that, when applied to the first column, would produce the same tax liability as a different rate schedule based on the third column. Indeed,

\section{REPORT 8-9.}

73 REPoRr 11, Table 7-1, columns 1 and 3.

Although the rate schedule that is actually recommended by the Report is not wholly consistent with these assumptions about the ratio of discretionary economic power to total income, it is heavily influenced by them; and the departures are explained by the need to reconcile conflicting objectives. Thus, the recommended schedule is contrasted (3 REPORT 165) with a hypothetical "ideal" schedule that would be "consistent with all of the assumptions that would result in taxes being levied strictly in accordance with ability to pay." 
the Commission's own calculations show how parity can be achieved.

This possibility of converting the tax burden imposed by one rationale into a comparable burden to be reached in another way, however, creates a resemblance between them that is both superficial and misleading. This is because the dynamics of the two theories are different. Claiming to take account of the way taxpayers actually use their income, the Commission's theory invites the correction of its rules of thumb by a study of behavior in real life; the distinction between "discretionary" and "non-discretionary" expenditures, that is to say, implies the existence of patterns that can be ascertained by observation. ${ }^{8}$ If, for example, all taxpayers with $\$ 25,000$ of aggregate income spend at least $\$ 3,000$ on housing, it would not be unreasonable to conclude that the "appropriate standard of living" for taxpayers at this income level requires an expenditure of $\$ 3,000$ for housing, and to put this amount on the "non-discretionary income" side of the family budget. Another approach would designate as "non-discretionary" the average amount spent for housing by taxpayers at this aggregate income level, or the average amount spent by the more parsimonious half of this group. Having selected a standard of normality from among these (or other) possibilities, we could then apply it successively to each category of personal expenditures entering into the cost of living, in order to determine the cost of maintaining the "appropriate standard of living" at each income level. "Discretionary income" at each level ${ }^{9}$ would then be computed by subtracting this non-discretionary cost of living from the aggregate income. The figures emerging from this statistical examination of normal expenditure patterns would then be substituted in the third column of the table above for the figures derived by the Commission from its intuitively-constructed second column.

To compute the total amount of income that, at each economic level, is devoted to non-discretionary uses, we would need to specify the relevant categories. Although the Commission does not specify its chosen categories, food, lodging, and clothing are surely included, along with normal medical costs (extraordinary medical expenses are to be accounted for separately), and, one may suppose, recreation; and for

8 So little is known of the expenditure patterns of taxpayers above the subsistence level, at least in the United States and I presume in Canada as well, that entrance into this virgin territory would no doubt have unduly delayed completion of the Report if it had been regarded as a prerequisite to construction of a rate schedule for the proposed tax system. My point is that this barrier would become a challenge to legislative ingenuity in later years, and that studies could be devised to surmount it.

9 Or, if further breakdowns were desired, for each category of taxpaying unit (individuals, married couples, families, etc.) at each income level. 
families with children, some educational expenses are probably nondiscretionary. It may be that the Commission would characterize some investments in retirement plans, annuities, life insurance, and "rainy day" bank deposits as non-discretionary. Acceptance of the "discretionary income" concept, of course, does not necessarily entail use of the same categories of non-discretionary expenditures that the Commission may have had in mind. Applied to another set of categories, the concept would produce a different array of discretionary income figures for each income level. Much would also turn, in any statistical study, on the way specific items are assigued to broad categories, e.g., restaurant and hotel meals might be classified as food or as recreation; a second automobile, as transportation or as child support; a television set, as furniture or entertainment; etc.

"Discretionary income" may, at first glance, suggest that the concept requires a ranking of expenditure categories, from those most necessary to life (e.g., food and lodging) to those that some taxpaying units do not incur at all (e.g., charitable contributions). Such judgments could be avoided even if all categories of expenditures are taken into account, however, provided the statistical study described above established an irreducible budget for each income level, representing (for example) the average amount spent on each category by the more parsimonious half of the taxpayers at that level. The "discretionary income" theory, in other words, does not require us to assume that some categories (e.g., food and shelter) are less "discretionary" than others (e.g., recreation).

What is unavoidable in the theory, however, is a bias in favor of income levels whose taxpayers are homogeneous in their tastes. Thus, if all taxpayers at the $\$ 10,000$ income level spend the same amount on housing, food, and each other category of expenditures, and all categories are taken into account, there will be no discretionary income at this level. Although homogeneity in so pure a form would not be encountered at any income level, some levels may be more uniform in their expenditure patterns than others. If so, discretionary income-in the sense of the amount available for items that others on the same income level do not buy-may diminish in fractional or even absolute amounts as we go up the income scale, or may rise and fall in a capricious curve. Moreover, homogeneity would make itself felt even if the categories of expenditures qualifying as non-discretionary were limited. Thus, if food, shelter, and clothing were the only categories taken into account in computing non-discretionary income, a study of expenditure patterns might disclose (for example) that the average taxpayer at the $\$ 25,000$ level spends as high a fraction of his total income on these "non-discretionary" items as the average taxpayer at the $\$ 15,000$ level, 
with the result that the discretionary income at the higher level is greater in absolute amount, but not when expressed as a fraction of total income.

The Report's advocacy of discretionary income as the proper measure of taxable capacity also invites us to explore a tailor-made tax, precisely fitted to each taxpayer's discretionary income, by allowances for his actual expenditures on the relevant non-discretionary categories, up to the amount considered appropriate to his income bracket. Were such allowances to be substituted for the aggregate allowance for non-discretionary expenses recommended by the Commission, a taxpayer who spent less for non-discretionary items than others in his income bracket would pay a higher tax in recognition of the larger residue of discretionary income at his disposal, although no one would be allowed to deduct more for such items than the amount determined to be "appropriate" to his income level. An analogue may be found in the Commission's willingness to "individualize" expenses for medical care and for the support of close relatives, which are treated as non-discretionary expenditures to be accommodated by special allowances, rather than by the blanket allowances for non-discretionary expenditures built into the table above. A comprehensive effort to compute discretionary income by reference to the actual expenditures of each taxpaying unit might well have to be rejected because it would overload the administrative and enforcement machinery, but it is not inconceivable that some categories of non-discretionary items could be identified for which separate treatment on a taxpayer-by-taxpayer basis would be feasible. One can at least anticipate that a tax system based upon the Report's discretionary income concept will encounter in the future a variety of proposals to refine the concept by individualizing it; and the Commission's view of such efforts would have been welcome. Its willingness to grant the allowances mentioned above rather than to stand pat on the hypothesized fractions of non-discretionary expenditures at each income level may imply some sympathy for calculating discretionary income on an individual rather than aggregate footing.

Still another unexplored feature of discretionary income is its relation to the type of income received by the taxable unit. One can hardly exclude, a priori, the possibility of persistent differentials, linked to income source, in the percentage of total income devoted by persons in the same income bracket to the items that the Commission would treat as non-discretionary expenditures. Indeed, it seems likely that a taxpayer whose income consists wholly of dividends from inherited securities will have a siguificantly different amount of "discretionary income"-no matter how this concept is measured-than a taxpayer 
earning the same amount as a salary, and that both will be distinguishable from a taxpayer deriving that amount of profit from a one-man business. If this hypothesis is true, and I do not know what evidence can be adduced for rejecting it out of hand, an exponent of discretionary income as the most accurate measure of ability to pay would have to decide whether this tenet should take precedence over another premise of the Report, viz., that distinctions should not be based on the source from which a taxable unit derives its income. Since the Commission's reason for disregarding the source of income is that it does not affect the taxpayer's aggregate command over goods and services, I should think that this principle would have to yield, on the Commission's own argument, if discretionary income-the ultimate touchstone of ability to pay-varies with source. The Commission's concept of discretionary income, in short, does not harmonize with its insistence that the "source" of income would be irrelevant in a sound taxing system.

A related refinement in the tax base that is similarly invited by the Commission's own focus on discretionary income is a system of deductions and other allowances for income that is included in the tax base, but that cannot readily be employed for non-discretionary expenditures. $I$ have in mind income resulting from an increase in non-liquid assets (e.g., a sole proprietor's inventory or accounts receivable) or from a transaction that puts no cash in the bank (exchanges, debt cancellations, etc.); other examples can be readily offered. I am not sure whether the Commission would welcome an effort to refine the concept of discretionary income by allowances for such types of income, or would resist it in the name of administrative convenience or simplicity. Its theory of taxpaying capacity surely provides a framework entitling the advocates of such modifications to claim that they are apostles rather than heretics, since they will be asking for a more accurate measurement of the income that is available for use at the taxpayer's discretion.

The Commission's advocacy of discretionary income as the proper measure of taxpaying ability conflicts with still another criterion to which it pays homage, viz., a progressive rate structure. The Commission's "ideal" rate structure and, to a substantial degree, its recommended structure are based on a flat 50 per cent tax rate applied to discretionary income. At first blush, this suggests that the Commission was convinced that proportional taxation is the only just system, or at least that the case for it is less uneasy than the case for progressive taxation. A closer examination of the Report discloses, to the contrary, a repeatedly-expressed preference for, indeed an insistence upon the 
equity of, progression. ${ }^{10}$ To be sure, a proportionate rate on discretionary income can be converted-on the assumptions used by the Commission in computing the percentage of discretionary income at each level of total income-into a progressive rate on total income (and this is in fact done by the Commission); but given other assumptions about the relation of discretionary to total income, this might not be possible.

More important, one would expect a taste for progression to be satisfied only by progression in the rate applicable to the Commission's measure of taxpaying ability, viz., discretionary income. Yet the Commission has applied a proportional rate to this crucial concept; the rate is progressive only vis-à-vis total income, and even then, as a mere by-product of the relationship that the Commission hypothesizes between discretionary income and total income. A true believer in progression can hardly be satisfied if it is applied to the wrong measure of taxpaying ability, or if it emerges as an ancillary or accidental result of applying a proportionate rate to the "correct" measure. Thus, on another set of assumptions about the ratio of discretionary income to total income, a progressive rate applied to the latter concept might translate into a regressive rate on discretionary income. It is, therefore, puzzling that the Commission did not put its announced preference for a progressive rate into effect by applying it to discretionary income. This would have produced a steeper slope at the total income level, to be sure, but this fact would merely reflect an inability-given the Commission's assumptions - to achieve progression where it counts without getting a greater degree of progression where it does not count.

\section{AgGREgation OF FAMILY INGOME}

As a corollary of its concept of "discretionary economic power," the Commission recommends that Canada abandon its historic use of the individual as the appropriate taxpaying entity, and look instead to the taxpaying ability of family units by aggregating the income of married couples, including, in most instances, the income of their dependent children:

10 For example, 3 REPORT 153:

For the tax system to be fair, the taxes paid by upper income tax units should be a larger proportion of their total income than the taxes paid by units with less income. If the income tax were the only tax levied, a mild progressiveness in marginal rates would suffice. However, as Chapter 6 has shown, other forms of taxation are regressive. The income tax therefore must be progressive merely to achieve a proportional tax system. To obtain a progressive tax system the income tax must be markedly progressive.

Although progression is the dominant theme, occasionally (e.g., 1 REPORT 19) the Report seems to favor "the proportionate taxation of discretionary economic power." 
We believe firmly that the family is today, as it has been for many centuries, the basic economic unit in society. Although few marriages are entered into for purely financial reasons, as soon as a marriage is contracted it is the continued income and financial position of the family which is ordinarily of primary concern, not the income and financial position of the individual members. Thus, the married couple itself adopts the economic concept of the family as the income unit from the outset. In western society the wife's direct financial contribution to the family income through employment is frequently substantial. It is probably even more true that the newly formed family acts as a financial unit in making its expenditures. Family income is normally budgeted between current and capital outlays, and major decisions involving the latter are usually made jointly by the spouses. Budget decisions indirectly influence family saving and provisions for retirement, although these are frequently determined on a contractual basis through insurance and pension arrangements, both of which have implications for the family rather than for the individual directly involved.

Where the family grows by the addition of children, further important financial and economic decisions are made in the family as a unit. Questions of the extent of education, time of entrance into the labour force and, frequently, choices of a career are decided on a family basis, although of course there are many exceptions to this statement. In some circumstances the income of the child is added to the family income, and, even where this is not done directly, the fact that a child has income of his own will have some bearing on the main family expenditure decisions. Certainly when the child becomes self-supporting he is normally expected to relieve the family of further expenditure on his behalf. Thus, the income position of children has an important bearing on the family income, although frequently in an indirect way. ${ }^{11}$

Responding to this view of the family's taxpaying ability, the Commission proposes to permit, and by a special rate schedule virtually to require, a family return to be filed by certain groups of taxpayers, of whom the most important are: married couples (with or without dependent children); widows, widowers and divorced parents with dependent children; and dependent children whose parents have died. As to married couples, the family return will be familiar to U.S. readers of the Report; it is the proposed inclusion of dependent children (defined as unmarried residents of Canada, under 21 years of age or

113 REPORT 123-24. 
mentally or physically disabled-whether actually supported by their parents or not $)^{12}$ that challenges our attention. Under the proposal, it should be noted, a married couple may agree to file separate returns (though they will not pay less tax, and ordinarily will pay more, if they do), but dependent children must be included in a parent's return, unless the child or his parents elect independence under a restricted option to be described later.

Although a minor child's income may increase the family's "discretionary economic power" in some instances, self-imposed or even legal restrictions on the use of such income are not uncommon. A family understanding that an adolescent may spend his earnings or other income for what he regards as his needs, even if they are frivolous or repellent to his parents, might be thought by some to warrant exclusion of the child's income from the family unit's return, especially if such freedom is so endemic in the society as to be the rule rather than the exception. The case for aggregation becomes even more difficult if we posit a prohibition (enforceable at law or appealing to the conscience) on the parent's use of the minor's income to pay for his maintenance, causing the father to treat the child's resources as sacrosanct and to save and reinvest them until he reaches adulthood.13

Perhaps the Commission rejects these arguments and favors aggregation of the child's income with his parents' because the parents are freed, pro tanto, from the social pressure to save for the child's future and hence can spend their "own" income with greater insouciance. Having opted for aggregation, however, the Carter Report tempers its recommendation, in a way that will make it more palatable to some but less so to others, by the child's right to deposit taxable gifts, bequests and earned income in an Income Adjustment Account, a device having the effect of excluding these amounts from the family unit's income and holding them in abeyance to be taxed only on withdrawal or on the child's departure (ordinarily at age 21) from the family unit. This formidable option could call for some nerve-wracking calculations, in which the advantage of reporting the income at the minor's own tax rate at age 21 (or at a later time if the child remains a member of the unit longer) would have to be balanced against the loss of yield in the interim. ${ }^{14}$

12 Children between 21 and 25 attending a university or other full-time program of secondary education may be included in the family return if they and the parents consent (3 REPORT 133).

13 If the child's income can legally be used for luxuries but not for "support," uncertainty over the scope of the latter term (infra note 17) may lead the father to refrain from using the child's income for any purpose.

14 Although the Income Adjustment Account would be interest-bearing as respects gifts 
For some, deposits in an Income Adjustment Account would be a satisfactory way of nullifying the recommended aggregation of family income, but this possibility should give us pause. Can one reconcile the Commission's conviction that an accurate measure of the family's discretionary economic power requires aggregation, with its willingness to have some families avoid aggregation if their discretionary power over the child's income is exercised in a particular way, viz., by depositing it in an Income Adjustment Account? The question is even harder to answer in the affirmative if we assume that some families will eschew the option because they are not rich enough to be able to save, or will prefer a more venturesome investment than an Income Adjustment Account, or will be wary of the unpredictable consequences of dumping income realized over a number of years throughout the child's minority into a single year's return when he reaches 21 (a result that may be only palliated by averaging).

The Commission provides an anti-aggregation option to accommodate a limited number of families whose children have income of their own. A child who is over the school-leaving age, who does not live with his parents, and who is employed or engages in business on a fulltime basis, may elect to withdraw from the family unit and file as an individual. Although the option is intended for a child who "for one of a multitude of possible reasons, becomes self-sufficient at an early age," self-support is neither a necessary nor a sufficient condition: the option can be exercised by a child who is supported by his parents if he lives apart from them and has a job or a business (even if his earned income is zero or the business produces a loss), while it cannot be exercised by a self-supporting child who lives with his parents. ${ }^{15}$ If the provision was intended by the Commission to focus on the child's self-sufficiency rather than on self-support, moreover, one wonders why a child who is financially independent by reason of inherited wealth, and who cuts the apron strings by living apart from his family, cannot elect out of the family unit even if he prefers leisure or study to employment.

The more one reflects on the social, economic and psychological

and bequests (but not for earned income), I should suppose that most taxpayers would believe that they could achieve a better rate on their own investments than on an Income Adjustment Account.

15 Strictly speaking, this option turns on the child's occupational status rather than on the source of his income, being open to him even if his business or employment produces no net income. But the provision is clearly motivated by the view that a child's income from employment or business ordinarily, or at least often, contributes little to the family unit's taxpaying ability. This persistence of source as a criterion of tax distinctions, despite the Report's repeated denial of its relevance, suggests that there may be more to it than is acknowledged, and that distinctions based on source ought to be assessed in a less grudging or dogmatic spirit. 
well-springs of this anti-aggregation option, the more one wonders whether the major premise which it rejects in a very timid way-aggregation of the income of minor children in the interest of an accurate measure of family economic power-is as realistic as the Commission recommends. Perhaps the existing income tax structure of the United States and Canada, which accepts the child as an independent entity with his own taxpaying ability, ${ }^{16}$ anticipated social or psychological conditions that were maturing in the womb of time when today's provisions were originally drafted. Many contemporary parents will find plausible, quite without regard to its tax implications for them, the suggestion that aggregation of the income of children would have been more appropriate in the nineteenth century than it is in the twentieth.

The aggregation of children's income with their parents', however, is not a readily detachable annex to the Commission's recommendations. It is, rather, closely linked with the proposal to require gifts and bequests to be included in the recipient's taxable income, and it is not clear whether one could survive without the other. With aggregation, it is not necessary to distinguish between a parent's gifts to his children and the discharge of his support obligation: transfers within the family unit are disregarded. Were minor children to be treated as independent taxpaying entities, however, this troublesome distinction would have to be drawn as a routine matter for innumerable familes in the middle and upper income brackets.

This in itself would be a formidable administrative task, for which experience has not yet provided reliable or easily applied criteria. ${ }^{17}$ Moreover-and this is at least equally important-the distinction presupposes that a child does not realize income when he is supported by his parents at the normal level for his station in life. This premise is acceptable enough in a taxing system that excludes gifts, bequests, and other transfer payments from the recipient's income, but it becomes distinctly questionable if these items are to be taxed. If it is "discretionary economic power" that measures one's ability to pay, what rationale can be offered for excluding support payments received from one's parents, while including in the tax base such receipts as gifts from other relatives, friends, or charitable institutions, unemployment compensation, strike benefits, etc.? To draw the distinction, we must reject pro tanto the Commission's repeated assertion that the source of the taxpayer's economic power is irrelevant.

16 Including (at least in the United States) a provision (\$ 73) for taxing the child's earnings to him even though his parents have a legal right under local law to appropriate them.

17 See Note, Federal Tax Aspects of the Obligation to Support, 74 HARv. L. Rev. 1191, 1192-1196 (1961). 
Even if we assume that support payments by themselves create no discretionary income (on the dubious premise that they never exceed the child's non-discretionary expenditures), they surely enter into the computation by permitting other income to be used for discretionary purposes. In this respect, they resemble charitable gifts, unemployment compensation, strike benefits, and similar transfer payments. If anything, indeed, a recipient of these categories of modest assistance is less likely to have anything left over for discretionary expenditures than a child who is supported by his parents.

The case for excluding support payments from the taxable base while taxing gifts and other transfers is made no stronger-perhaps it is weakened-if we turn from the child to his parents. In computing the parents' discretionary income, the Commission evidently regards support payments as non-discretionary expenditures (at least in part), presumably because they are made under legal compulsion and serve to maintain the parents' appropriate standard of living. Gifts to children, on the other hand, seem to be discretionary expenditures. If any significance is to be attached to this characterization at the parents' level, it would suggest that gifts-having come out of the parents' tax-paid income-are more entitled to exemption in computing the child's income than support payments, which have enjoyed an allowance at the parents' level. This reversal of the Commission's approach may not follow inexorably as we move from the parents' level to the children's, but it is more persuasive to me than its opposite.

This analysis leads me to these conclusions:

1. The proposed inclusion of children in the family taxpaying unit, though initially appealing, fails to take sufficient account of the independence, in today's social milieu, of adolescent youth.

2. If, contrary to the Commission's recommendation, children are treated as independent taxpaying entities, the inclusion of gifts and other transfer payments in the tax base of the recipient is objectionable unless support payments are also included.

\section{TREATMENT OF INTERMEDIARIES}

In keeping with its central emphasis on the discretionary economic power of individuals and family units, the Commission expresses an antipathy to taxing the income of corporations, trusts, and other entities:

Equity and neutrality would best be achieved under a tax system in which there were no taxes on organizations as such, and all individuals and families holding interests in organiza- 
tions were taxed on the accrued net gains from such interests on the same basis as all other net gains. ${ }^{18}$

Were this view of the proper tax treatment of organizations to be put into effect without reservation, it would be unnecessary to determine their income; the taxpayer would be concerned only with the net change in the value of his interest in the organization-an amount that would be influenced by, but far from identical with, the organization's realized income. Since the Commission rejects the net worth method of computing income as not feasible, ${ }^{10}$ however, it must provide rules for computing the income of organizations, and find other ways of integrating them into its tax structure.

The Commission's solution in the case of corporations is to tax their income at the flat rate of 50 per cent (the highest rate applicable to personal income), and to require the income, when distributed to the shareholder by the corporation, to be included in his tax base, "grossedup" to include the corporate tax. The shareholder would then be allowed a credit against his individual tax for the tax paid (on his behalf, so to speak) by the corporation, with a refund if the credit exceeded his liability. If the corporation did not choose to make an actual distribution, it could at its discretion allocate amounts to its shareholders for inclusion (grossed-up) in their personal returns; in this event, the basis of their stock would be increased pro tanto, so that there would not be a second tax on the sale of the shares. Having paid its way, income so allocated could be distributed tax-free, with an appropriate reduction in the shareholder's basis for his stock to reflect this tax-free return..$^{20}$ If income was neither distributed nor allocated to the shareholders currently, the "prepayment" represented by the corporate tax would become available as a credit at any later time when the corporation decided that it was opportune to distribute. The net result of the Commission's proposal, if the corporation either distributes or allocates its income to its shareholders in the year of realization-the normal response, in the Commission's view-would be a tax on the income at the shareholder's personal rate. If the income is neither distributed nor allocated, any increase in the value of the shares reffecting the retained income would be taxed to the shareholder at his personal

184 REPORT 4.

19 To the usual objection that annual valuations are not feasible, the Report adds the special fact that many shareholders of Canadian corporations are non-residents, who cannot be reached effectively except by a tax on the corporate income when it is earned. 4 REPORT 5.

20 This part of the proposal has a familiar ring to those familiar with Subchapter $S$ of the Internal Revenue Code of 1954. The Commission also provides explicitly for an optional partnership mode of reporting corporate income. 4 REPORT 68-70. 
rate when and if he sells his shares. The resulting "overpayment" (i.e., the corporate tax at the 50 per cent rate) would be corrected if and when the corporation distributes the previously taxed income to the new shareholder, since he would gross up the amount received in computing his taxable income, and would then claim a credit for the corporate tax.

When the Commission turns its attention to the taxation of trust income, with the same objective of taxing the persons beneficially interested in the, entity's income rather than the entity itself, ${ }^{21}$ it seeks to achieve a similar degree of integration by taxing the trust's income at the highest personal rate (50 per cent) and correcting for the possibility of over-taxation by a gross-up and credit at the beneficiary's level. Although this device is not without its difficulties as applied to corporations, at least two special problems arise when it is adopted for use in taxing trust income.

In the case of corporate income, one can ordinarily say with assurance that it inures to the benefit of an identifiable group of taxpayers, viz., the owners of its common stock. The beneficial owners of trust income, however, are often not identifiable when the income is realized, because it is to be accumulated for later distribution to persons whose identification depends upon future events, including in many instances the exercise of the fiduciary's discretion. This means that a current tax at the 50 per cent level on trust income-recognized to be an overpayment in many cases-cannot be currently corrected as the Commission expects it to be corrected in the case of corporate income, viz., by a current distribution or allocation. A second source of difficulties in fitting the taxation of trust income into the Commission's master plan for taxing natural persons rather than artificial entities is the fact that trusts are commonly created by gifts and bequests-transactions that themselves are taxable events under the Commission's proposals. Because the Commission exempts gifts and bequests that remain within the donor's family unit, however, a mode must be found for exempting gifts and bequests received by a trust for a donee whose relationship to the donor would exempt the transfers if the trust did not intervene.

The Commission's effort to provide solutions for these problems accounts for most of the complexities, which are formidable, in its recommendations for trust income. To reduce the frequency of overpayment resulting from the initial 50 per cent tax on the trust, the

214 REPORT 150:

As a conduit, the trust does not in itself have a taxable capacity, but rather represents the individuals who are its ultimate beneficiaries. Thus, any taxes levied on the trust should be regarded as having been collected on behalf of the individuals who are the ultimate beneficiaries of the income being taxed. 
Commission proposes to allow a beneficiary who can be identified with reasonable accuracy to elect to have the trust pay at his personal rate, with an attendant exemption at the trust's level. A parallel provision is recommended to forestall a tax at the trust level on gifts and bequests for the benefit of a donee who, by virtue of being a member of the donor's family unit, would not be taxable if the property had been transferred directly to him.

In describing these recommendations for the taxation of corporate and trust income, it is not my purpose to set the stage for an extensive examination of their merits. I wish rather to emphasize that the Commission, in keeping with its underlying premise that taxpaying ability is vested entirely in natural persons, consistently views corporations and trusts as conduits. Although not all "ability to pay" philosophers have offered similar recommendations, this view of business and financial entities is inherent in their arguments; and it can be assumed that few would disagree with the Commission's objectives, however unsure they might be of the details, practical feasibility, or political acceptability of its recommendations. The Commission is to be commended for its effort to give effect to an underlying premise that is frequently asserted but whose implications are rarely pursued in depth.

When the Commission turns its attention to co-operative and other mutual organizations, it similarly favors taxing the natural persons who benefit from the entity's activities, rather than the entity itself. As to co-operative societies:

In our view, the income of the co-operative should ultimately be taxed at the individual rates of the members in the same manner as the income of ordinary corporations should ultimately be taxed at the individual rates of the corporate shareholders. ${ }^{22}$

If the co-operative sells its merchandise at cost, there will, of course, be no income to distribute as patronage dividends to its members, and they will have no taxable income under the Commission's proposal even if they derive an economic benefit from the society's operations, in the form of an advantageous price for their purchases. If, on the other hand, the society follows the orthodox co-operative practice of selling at market prices, distributing the "profit" to its members at year-end, the Commission's proposal requires the members to report the distributions as income. To the extent that the dividend is attributable to business conducted with non-members, it can be regarded as business income inuring to the benefit of the member as entrepreneur-though 
the fact that the distribution is proportionate to his own purchases, rather than to the cost or value of his membership certificate, makes for a curious kind of entrepreneurship. Less explicable-indeed, quite dubious-is the inclusion in taxable income of dividends attributable to the member's own purchases from the co-operative. If he has an investment in the society, in the form of a membership certificate, the refund might be properly regarded as, in part, a return on that "investment." Since in practice a membership in a consumers' cooperative rarely if ever can be transferred for value, however, the member's patronage refund cannot be regarded as a return on his investment; to the contrary, the cost of membership has the economic consequence of reducing the patronage refund.

If the patronage refund on the member's own purchases is made possible by the society's ability to get a manager or board of directors to work for less than a market wage, out of devotion to the cause, the patronage refund could perhaps be characterized as a gift to the society's members by the underpaid idealists who manage the societythough a "gift" that is proportionate to one's purchases is an exotic concept. If the society's profit, and therefore the patronage refunds, reflect the value of uncompensated (or under-compensated) services performed by the members themselves, the Commission is moving into the area of imputed income. If the lawyer is not taxed when he writes his own will or repairs his personal residence, should he be taxed on patronage refunds reflecting the value of his services (or his wife's) to the co-operative paying the refunds? Finally, it may be that the patronage refund is possible only because the co-operative's price for its goods exceeds their fair market value. This seems a reasonable hypothesis if the member purchases them from the society in anticipation of a rebate at year's end, and it is inconsistent with the notion that he has realized income in the process. If, on the other hand, above-market prices are possible because of the gullibility of the members, ${ }^{23}$ the refund is better characterized as the recoupment of a potential loss than as realized income.

Since the members of a co-operative society would not be required by the Commission to report any income if the co-operative society reduced its prices at the outset by the amount of the anticipated patronage refund, its insistence on taxing such distributions as income seems to me the pursuit of a will-o'-the-wisp. The same may be said of the

23 If he is sufficiently fearful of the hidden persuaders of Madison Avenue, the member of a co-operative society may assume unjustifiably that the bureaucracy of his organization is more efficient than its capitalist competitors merely because it professes a different ideology. 
parallel recommendations taxing interest rebates paid by credit unions and policy dividends paid by mutual insurance companies: should income arise on the refund of an amount that would not have been taxed if received at the outset of the transaction in the form of a reduced initial price? This question has been answered in the negative, in effect, by the Commission in its recommendations for the taxation of private clubs. Such an organization's income from membership activities is not to be taxed, presumably because a reduction of the club's charges to its members would be an easy way of aborting the emergence of income. This reasonable approach to the income arising from a social club's dealings with its members could be appropriately adopted, in my opinion, in dealing with patronage dividends, interest rebates, and policy dividends received by the taxpayer from consumers' co-operatives, credit unions, and mutual insurance companies.

In its examination of two other classes of traditionally tax-exempt organizations (government corporations performing "proprietary" functions and charitable organizations), the Commission is much troubled by the possibility of unfair competition between the exempt organization and private enterprise. In the case of government corporations that compete with private companies-railroads, telegraph companies, hotels, gas and electric companies-the Commission favors taxing their income; ${ }^{24}$ and if shares of a private business corporation are owned by a governmental body, the Commission proposes to deny the usual credit allowed to a shareholder on distributions.

There is an irreconcilable conflict between the Commission's principle that income taxation should be related to the economic status of natural persons and its desire to equalize the competitive positions of rival businesses by equalizing their taxes. If an income tax exemption improperly interferes with competition by favoring the exempt business, it follows that a similarly unfair (though less substantial) advantage is enjoyed by a business subject to a low tax rate. ${ }^{25}$ Since the Commission's recommendations contemplate that the natural persons who own a business are to be taxed rather than the entity itself, a corporation

24 Subject, in the case of companies owned by Canadian provinces, to the inter-governmental immunities created by the British North America Act.

25 Were it to be applied to the United States, this effort to equalize the competitive race between rival businesses would evidently require the imposition of an additional tax, or other special treatment, for businesses owned by taxpayers with large deductions for percentage depletion, intangible drilling and development expenses, casualty losses on personal property, etc.-lest their business compete unfairly with businesses that are taxed at the regular corporate or personal rates because their owners do not enjoy these extraneous tax benefits. Subchapter $S$ is another tax provision that would have to give way if tax burdens are to be equalized in the interest of free enterprise. 
owned by low-bracket shareholders would evidently enjoy a competitive advantage over a corporation owned entirely by rich shareholders.

Those in the United States who fear that if charities were not taxed on their unrelated business income, they would crowd out private business, should, therefore, be wary of the Commission's proposal to integrate the corporate and personal taxes-by giving a competitive advantage to the poor man's business, it may enable him to inherit the earth, or at least that part of it lying north of our border. Conversely, this competitive advantage might be approved by some as a maneuver in the war on poverty. Whether it is viewed with favor or distaste, however, the existence of this pervasive differential suggests that the Commission's effort to equalize one small segment of the competitive struggle-competition between exempt and taxable businesses-is hardly worth the candle. ${ }^{26}$

The conflict between the Commission's dedication to a progressive rate structure and its desire to equalize the competitive struggle emerges with special clarity when we examine its recommendations for charitable organizations. Calling attention to its recommendation that the donees of charitable gifts be required to include them in the comprehensive tax base, the Commission is content in general to exempt the charity's own income. So far, the Commission's recommendations for charitable organizations harmonize with its proposals for business corporations, trusts, and other intermediaries - the entity is treated as a conduit, whose income is to be taxed to the natural persons who receive it. In some circumstances, to be sure, the charity's income will be permanently exempt from tax, because no identifiable beneflciaries will be taxed on the benefits dispensed by the institution. An example is the private university; perhaps it is thought that society at large is benefited, rather than the students, and that it is as impossible to allocate these benefits to their widely-dispersed recipients as it is to allocate the benefits of fire and police protection, public school education, and national defense. ${ }^{27}$ In other circumstances, an identifiable beneficiary of charitable receipts may pay no tax, if his income does not exceed his exemptions and deductions; but this is as it should be, since the "ability to pay" of natural persons is the Commission's touchstone for taxability. Having thus proposed a framework for the taxation of charitable

26 The pursuit of government-owned businesses is also quixotic, in that the imposition of a tax on their income would do little to equalize the competitive struggle unless accompanied by a prohibition on governmental grants, supervision of the allocation of expenses and overhead if any of their functions are performed by regular government departments, etc.

27 See Bittker, $A$ "Comprehensive Tax Base" as a Goal of Income Tax Reform, 80 HaRv. L. REv. 925, 936-938 (1967). 
organizations that is built, with appropriate adjustments, on the "conduit" principle used for corporations and other financial intermediaries, the Commission proceeds to confine this sensible treatment to the charity's "portfolio" income. Non-portfolio income-including income from real estate, operating a business, and even dividends if the charity owns 10 per cent or more of the stock-is to be taxed, ${ }^{28}$ with no provision for tracing the tax burden through to the charitable beneficiaries in order to allow them a credit. The objective is to protect taxable businesses against competition from tax-exempt operations:

[T] here should not be any tax concessions that give one business a competitive advantage over another, and the present exemption of business income earned by charities could well be regarded as such an advantage. ${ }^{29}$

To eliminate this "competitive advantage," the charity's business income (as defined above) is to be taxed at a flat 50 per cent rate, without regard to the financial circumstances of its actual or potential distributees. Thus, even if the income is irrevocably devoted to the welfare of persons who are completely destitute, it is to bear the heaviest tax burden that is possible under the Commission's rate structure, in disregard of the Commission's own salutary principle of looking to the natural persons who bear the tax burden, rather than to the legal form used in carrying on the activity. If the charity's beneficiaries are not totally destitute, but are rather in the taxpaying population, their income from charitable gifts would be subjected to a combination of a tax of 50 per cent on the entity's business income and a tax at the individual's personal rate-a heavier burden than is imposed on a millionaire shareholder of a business corporation, for whom the Commission's integration proposal would limit the aggregate rate to 50 per cent. Moreover, in recommending a tax on the charity's business income, the Commission departs from its repeated insistence that the source of income is irrelevant in determining economic well-being, since the proposed tax depends on the source of the income, and on nothing else.

If the Commission's principle for taxing other financial intermediaries were to be applied consistently to charitable organizations, they would be treated as conduits, whose income should be taxed only to their beneficiaries. Perhaps it would be too cumbersome to achieve this objective by taxing the institution, and allowing its beneficiaries

$28 \mathrm{As}$ is usual with such recommendations for taxing some but not all of a charity's income, no serious effort is made to explain why the exemption of "active" income confers a competitive advantage that does not arise from the exemption of "passive" income.

294 REPORT 131. 
a credit when they receive gifts or other benefits, the system recommended by the Commission for taxing trust income. In the alternative, however, the Commission might have preserved the exemption of the charity, recognizing that the increased amount thus made available for distribution to its beneficiaries would have to pay its way when received by, and taxed to, them. If all the income of a charity is received by natural persons who pay no taxes because they are below the exemption level, the Commission should not look for a corrective, but rather should be pleased that its theory is bearing fruit. The immunity is no more to be deplored than is the fact that the income of a trust or corporation will bear no tax burden if it is fully distributed to persons below the exemption level.

Finally, the Commission contemplates a continuation of the existing Canadian deduction for charitable contributions, limited to 10 per cent of the taxpayer's income, with a possible increase to 15 per cent after its new rules relating to the charity itself have been in effect for a trial period. If a taxpayer's contributions are viewed as a dedication of his income to the charitable beneficiaries, however, an unlimited deduction would be quite defensible, on the ground that the benefit of the donation inures more to the donees than to the donor. On this theory, income devoted to charitable purposes would be taxed at the rate-and only at the rate-appropriate to the recipient. To be sure, the donor might be regarded as an appropriate taxable object, on the ground that he enjoys the satisfaction of making a charitable contribution. It would not be unreasonable, however, to think of him as a conduit, whose enjoyment of the funds is less significant than the use made of them by the charitable beneficiaries. Balancing the desirability of subjecting the original income stream to two taxes (one on the donor, and the second on the donee) against the case for looking exclusively to the recipient in measuring the tax due, the latter theory seems to me more plausible-given the Commission's "ability to pay" rationale-than the former.

\section{Conctusion}

Many students of income taxation have placed their faith in a comprehensive tax base in the hope of achieving a simple and non-controversial tax structure, to replace the complexities, compromises, and conflicts that make up today's law. In finding confirmation for their hopes in the Carter Commission's report, they may have overlooked some of its complexities, compromises, and conflicts. The three areas that I have discussed in this article-discretionary economic power, the aggregation of family income, and the income of business entities 
and other intermediaries-bristle with questions to which there are no "expert" answers; at every turn, judgments are required that cannot be divorced from one's social and political preferences. The Carter Commission's Report is an outstanding intellectual achievement, but it is an installment in a debate over tax policy, not a final solution. 